\title{
11 \\ INDUSTRIAL DEVELOPMENT AND LOCAL INDUSTRIAL SYSTEMS IN POSTWAR FRANCE
}

\author{
Political economy of a transformation \\ Bernard Ganne
}

\section{INTRODUCTION}

Starting from observations in postwar Italy (cf. Bagnasco's Third Italy, 1977) there has been a rediscovery of the importance of the territory in general and localities in particular in the organization of production. The local dimension, long overshadowed by concern with the macroeconomy, has reemerged as an object of concern. This is due in part to the rediscovery of the variety of economic forms that constitute an alternative to the mass production system that had come to dominate the economy in many countries (Sabel and Zeitlin 1985). It is also due to attempts to anticipate developments by observing a congruence between these older forms of industrial organization and the new ones based on flexible specialization (Piore and Sabel 1984). In light of the performance of the Italian districts, and as if to compensate for decades of neglect, the local area is making a comeback as a new paradigm of industrial development.

\section{A new hegemonic paradigm?}

Not long ago, structuralism was hegemonic in French economics and in sociology. For the structuralists, the local is nothing more than the projection onto a small screen of major macroeconomic forces. Ironically, it is often those who were the most ardent supporters of the school of development economics, which favored self-perpetuating industrialization ("industrie industrialisante"), who have become the most ardent defenders of territorial and local modes of development (Courlet and Judet 1986a, 1986b). This type of about-face appears to be leading to the development of a new hegemony which, in my view, is as damaging as the old one.

First, the Italian example was too rapidly turned into a model which uncritically champions endogenous growth. The success stories are celebrated, but the real lessons of the districts are not being learned (Michelsons and Baptiste 1989; Courault and Romani 1990; Ganne, 1989d).

Second, the current focus on the few zones in France that are most similar to the Italian districts (Cholet, the Jura, etc.), masks the fact that these zones are exceptions. In France there are few phenomena truly analogous to those observed in Italian industrial districts. 
By stressing the direct similarities between types of local development in the two countries, one misses the real question: in which political context do these local dynamics occur? Surely they have different meanings in the centralized French system than in the decentralized Italian one. Undue fascination with the success of Italian industrial districts thus forecloses precise assessments of the importance and place of local industrial systems in general.

A study of the French case responds to these difficulties by permitting the district phenomenon to be put into a theoretical perspective, which underscores its link with the political system. Until the postwar period, local industrial systems occupied a relatively important place within the French productive system. But then many of them disappeared just at the moment when the Italian districts began to prosper and proliferate.

The first part of this chapter contrasts the evolution of French and Italian districts, showing that an effective mobilization of endogenous potentialities is insufficient to guarantee the survival of localized industrial systems. Not only did the social, economic, and political integration of the communities fail to guarantee their survival, but it even contributed to their decline by helping to close the local economy off from the outside world. It was from the exterior, by means of state intervention, that these involuted systems were reopened.

The second part of this chapter draws out the lessons of the French case by showing to what extent the very constitution of local industrial systems depends on political factors.

Methodologically speaking, it would nonetheless be a mistake to think in terms of a local/global opposition, of endogenous versus exogenous forces, or of local cultural forces versus economic and political forces. The point, rather, is to understand the different ways in which the construction of the local is authorized by the political in France and in Italy: the comparison illuminates not only the internal structure of districts, but the type of relation established between the different systems and their environments. Thus, rather than an element-by-element comparison, each system must be taken as a whole, of which its politics forms an important part.

\section{PLACE AND EVOLUTION OF LOCAL INDUSTRIAL SYSTEMS IN FRANCE: SOME CONTRASTS WITH THE ITALIAN DISTRICTS ${ }^{1}$}

In the interwar and early postwar years, France had a large variety of local industrial systems, all characterized by the importance of small family firms. Often these were well integrated with each other. This system disappeared during the 1960s, at the very time when a similar form of economic organization began to gain importance in Italy. Why?

From the 1950s onward, French industry - including the Paris basin, all the regions of the north, the northeast and the southeast-was marked by extensive restructuring (Browaeys and Chatelain 1984). Even so, the variety of industrial systems-and the systems of small firms in particular-remained important. These included the systeme Motte in the north, consisting of federations of family firms; the aristocratic system of paper production in Annonay (Ardèche); cutlery in Thiers; the textile centers of the Vosges; the small metallurgy and watchmaking industries of FrancheComté; and finally the silk industry in Lyon (Sabel and Zeitlin 1985). These systems joined communities of 
persons and populations of firms via networks of artisans and merchants in historically bounded industrial districts (Becattini 1987).

Paradoxically, it was perhaps these links - or rather the concern to preserve them as they were - that contributed to the disappearance of the local industrial systems. The rigid maintenance of these systems put the defense of the status quo before the problem of adaptability, thus blocking the economic adaptation. A dirigiste modernizing current, created at the end of the 1930s, was able to make its mark effectively after the war by organizing economic concentration, (cf. the X-crise group, Bonin 1988:11). This was aided by the fact that collaboration with Vichy had politically discredited the patronat.

Thus, contrary to what is observed in the Italian case, local integration of the industrial systems does not always guarantee openness or adaptiveness. For French postwar planners, these systems constituted just so many obstacles to be removed. It is thus the massive disappearance of former local industrial systems that characterizes the postwar period in France, with the exception of certain specific cases to which we now turn.

\section{Diffused industrialization and localized industrial systems: limited developments}

It was only in certain zones that there developed in France phenomena similar to the Italian industrial districts. In the west these zones include the Choletais in Anjou, and the Vendée. In the east they include the Savoys, the Monts du Lyonnais, and the Jura. Given what is, after all, in France, the recent interest in problems of districts and diffused industrialization, one might suspect that this meager harvest reflects only the deficit of research on the theme. And the inventory certainly remains to be completed. But it is also true that outside of these principal zones, industrialization has not spread in France as dramatically as in the north-east-center of Italy and the 70 area-systems listed by Garofoli (Garofoli 1981, 1985). The reason for this is perhaps that in France such zones are exceptional, isolated culturally, politically, socially, and even economically.

As Bagnasco and Trigilia's observations regarding the white zone of Bassano and the red zone of the Val d'Elsa (Bagnasco and Trigilia 1984, 1988) suggest, diffuse industrialization and localized industrial systems have developed in France in ideologically specific zones, places which cultivate a certain political, social, and religious autonomy from the rest of the country.

In the Vendée and Cholet, we thus find wholly "white" zones, formerly royalist and very Catholic, marked by an ancient opposition to the Republican state; and these characteristics are equally marked in the Monts du Lyonnais. In the Jura and areas such as Oyonnax, it is rather the old socialist and libertarian tradition of the nineteenth century, and also the Utopians, that seem to have played a crucial role, and these traditions are reflected in a type of development based on craft firms.

In recent years, all these zones have had grown rapidly. Examples are the shoe industry in Cholet and plastics in Oyonnax. The organization of flexibility in these regions is reflected in the way they have succeeded in adapting to crises, even using them to facilitate renewal (changes in the productive system in the case of the shoe industry, adoption of new techniques in plastics, etc.).

These zones in a sense cultivated their autonomy, favoring internal complementarities 
and looking first of all within themselves for solutions to their problems without, however, closing in upon themselves as did local industrial systems.

In contrast to the preceding examples, where the local order hindered openness to the market, here openness to the exterior, and the adaptativeness which this implies, constitute the best guarantee of the longevity of the local system.

\section{Networks of small firms: more and more delocalized developments?}

Much recent analysis has shown the superior adaptiveness and capacity for offensive flexibility of small firms. Numerous studies have also shown the importance in France of this type of development in the creation of firms, the transformation of the industrial tissue, and the development of technopoles.

Yet even though these new dynamics may sometimes take place on a local basis, they seem in fact to depend more and more on the formation of professionalized networks, which are not restricted to the local level. Recent studies of French technopoles has shown, for example, how little articulation there is between the strictly local milieu and the small established firms: local firms are more competitive than they are cooperative (Chanaron, Perrin, and Ruffieux 1988). A number of studies of old industrial regions have also uncovered the radical degradation of the horizontal solidarity system (de Banville 1984). Our comparisons-Annonay in France and the Val d'Elsa in Italy-have also shown the different dynamics of these two countries (Ganne et al. 1988). We observed in Italy a reterritorialization of activity at a wider regional scale, while in France we found increased mobilization of external resources in the form of professional networks: the change in the social model of the firm seemed thus to be accompanied by a transformation of what has been called the territory-zone into a territory-network (Leborgne and Lipietz 1988).

In view of these latter developments it would seem that the texture of the industrial tissue is becoming less and less "local", in the Italian sense. This hardly suggests development of industrial districts on the Italian model.

Thus we observe in the French case that:

1 whatever their strength in terms of local structuring, local industrial systems may disappear; and that they have in large part already disappeared;

2 in recent times the reemergence of industrial districts in the Italian sense has not in fact occurred except in isolated and circumscribed cases; and

3 such recompositions of small firm systems as do exist seem to follow a logic where the strictly local aspect now plays a relatively restricted role.

This suggests striking contrasts, point by point, to almost everything that has been observed in Italy. The Italian districts had their phase of full development at the very same time that France, under the effect of a massive movement of concentration, witnessed the disappearance of old local industrial systems. And it was also the case that - at the very time when, following the crisis, a certain reterritorialization of activities seemed to be taking place in Italy - in France there seemed to be a deterritorialization of the small firm networks. 


\section{A POLITICAL ECONOMY OF LOCAL INDUSTRIAL SYSTEMS: AN INTERPRETATION OF THE FRENCH CASE}

A relative closure of local industrial systems, a preponderance of state action over that of the main economic actors, delocalizations resulting from local policies: localized dynamics observed in France seem in this way to obey completely different rules from those usually considered to hold in the Italian case. Could the explanation be that the dynamics of the local industrial systems in France depend on other factors?

\section{Economic Malthusianism and local industrial systems}

We noted above that localized industrial systems were quite important in the interwar period in France. To understand the particular position and evolution of local industrial systems in France - and their relative closure - recall that the period was marked by a Malthusian economic strategy backed up by the central state.

The greater persistence in France than elsewhere of localized systems (in the 1930s, France had a much less concentrated industrial structure than England or Germany) is due more to the fact that the prevailing Malthusian economic strategy reinforced these systems than to their internal, autonomous dynamics.

This economic Malthusianism consisted of a policy of promoting accords and cartels, and resulted in involution and closure of the districts ${ }^{2}$. As A.Sauvy wrote:

The [Malthusian] spirit permeated all of the legislation of the crisis, and even the pre-crisis. Conservatives and socialists tried to combat the crisis by acting on the symptoms: scarcity, to drive up prices, underproductivity, to increase employment, protection and closure of professions-these remedies accentuated, at the national level, the very problems they were intended to combat. No [other country] was affected to the same degree as France by such a serious problem.

(Sauvy 1984:413).

In 1919 reconstruction was too rapid and ambitious. Many firms simply rebuilt their prewar factories, with no effort at modernization. The new was already outdated (Bonin 1988:50). As late as 1931, in spite of some concentration in a few branches and increased vertical integration, French industry was still much more fragmented than its neighbours: the capitalization of Saint Gobain and Alsthom, the two largest companies of the time, was only a fifteenth that of the British ICI or the German I.G.Farben. The electrical industry was divided among many firms: no less than two thirds of the industry's workers were employed in firms with fewer than 100 workers, with 40 percent in shops with fewer than 10 employees (Kuisel 1984:158).

Essentially, French industrial development was based on networks of small firms, with management remaining individualistic, rooted in family capitalism, and firms serving regional markets. Firms were not geared to conquering larger markets, preferring instead occasional associations to fusions (Bonin 1988:65). They were wary with regard to 
outside finance, which was pejoratively regarded as the domain of speculators, merchants and "pirates" (Sauvy 1984:104).

In this period the main fear was overproduction. Although management resisted the dirigiste practices the state had adopted during the war, after the armistice it soon renewed the demand that the state regulate competition. This included restriction of external competition through protectionism-customs duties doubled on average in 1931-but also, and above all, restriction of internal competition through the authorization of understandings and cartels (Bonin 1988:92). The colonial empire remained for its part a privileged domain reserved to French industry.

In this way the understandings multiplied. Subtle distinctions allowed legitimated gentlemen's agreements (thanks to a law of 1926) and even created incentives to reach such agreements. They were now not only permitted but encouraged. In 1935 a bill designed to require participation in such understandings failed only narrowly (Sauvy 1984:114; Bonin 1988:94). It was believed at the time that fixing prices and setting production quotas was the best way to balance production and consumption. Overproduction was to be avoided by limiting competition, which lowered prices to the level of marginal costs, and ruined firms (Sauvy 1984:111-12). The use of understandings expanded considerably in this period; according to Sauvy, on the eve of World War II there were between 1,000 and 3,000 agreements (Sauvy 1984:117, note 1).

Certain trades and industries could thus be organized as closed associations, the most extreme case being the shoemakers and shoe-repairers: after the forty or so instances of direct regulation of the shoe trades by the state, the Le Poullen law of 22 March 1936 required authorization of the Ministry of Commerce two years in advance of the opening of any factory or workshop, as well as any enlargement or relocation of an existing factory. On 7 April of the same year another measure instituted the shoe-repairers' monopoly: fear of an incursion by Bata and its modern methods motivated a five-year prohibition on the opening of any workshop or repair booth (Sauvy 1984:115).

This "republic of the holes in the soles," as it was called, may seem humorous now, but it reflects well the general opinion of the time: F.Ditte, writing in Le Figaro in 1931, for example took pride in "our timid, prosperous economy,"3 and compared it to the "presumptuous, decadent" economies of the Anglo-Saxon races (Sauvy 1984:103). The state intervened in more and more details. The result of such policies was that the real degree of competition approached zero in the France of the 1940s (Caron 1981:365).

This policy guaranteed the status quo, but was incapable of dealing with the concentration of firms and the necessary transformation of the industrial structure relative to 1900-30 period. It resulted in a freezing of investment whose main effect was a decline of almost 20 percentage points in national income between 1929 and 1938 (Bonin 1984:94). Less rich and less dynamic, this is how France appeared just before World War II (Bonin 1986:97).

It is against this background that one should look at the persistence of localized industrial systems in France just after World War II. These systems had little openness to the exterior and were organized to defend the status quo, while the locale itself was more segmented than unified due to the fact that each branch attempted to preserve its link with the state and not with other local producers.

It is not, as in the Italian case, the autonomy of the zones and their structural 
independence with regard to outside authority that is most important here. Rather it was precisely through their articulation to the national political structure that the local actors seem to have been defined. The "Malthusian state" used the preservation and renewal of local systems as the vehicle for the gradual evolution it sought, with local actors expecting the state in return to guarantee the status quo. But the circle was closing in upon itself. It was thus not in spite of nor in the absence of the state that the different local industrial systems persisted in France before the war, but thanks to the state and in close contact with it. The "Notable-system" was key to local power in a centralized political economy (Grémion 1976).

Annonay is a case in point. I began studying the zone with the idea of finding an industrial ensemble of local small family firms that were closely interconnected. I supposed that the interconnection was threatened by the concentration of capitalism. I was thus astonished to find a highly segmented economic and social space, divided between the vocational community of the leather goods industry and that of the paper industry. These two communities had essentially no overlap (Ganne, 1983a). They rubbed shoulders in a restricted space, with the small firms of the leather sector functioning among themselves as a separate industrial district, while each of the different paper mills remained rooted in a kind of "estate-based, aristocratic" management applied to industry. There were few links between the two industries. The leather-working sector was marked by a specific system of cooperation/competition that developed work force mobility, playing on complementarities on the level of orders as well as that of techniques. There was also a system of reciprocal money drafts, under the benevolent eye of the local bank, which created a system of mutual insurance to cover unforeseen circumstances.

Otherwise, however, the local universe was socially, economically, and politically highly fragmented among different industries, each group relying more on its own activity than on the local system for the solutions to its problems. The fields of intervention of the local economic and political institutions were carefully delineated with the social and equipment side being the concern of the local public bodies, and the economic that of the Chamber of Commerce. Interference between fields of authority was not tolerated.

In short, this was a local system that was highly fragmented between both the economic and the political and the different branches of industry. The key to this segmentation was the type of vertical relation that each body cultivated with regard to the central power. Through negotiations with the state, each industry sought guarantees of its market and the reinforcement of the status quo, as in the policy of understandings and cartels. This fragmentation was also supervised, on the political level, by the notable system. The notable's function was to guarantee and promote diversity and to broker relations with the external world and the central political power. This was the source of both his strength and his weakness: at base, his power was both guarantor of and hostage to the status quo (Worms 1966; Ganne 1985). As the interface between the community and society in general, the power of the notable thus depends directly on the centralized character of the state. We are a long way, here, from the notion of autonomous local power as it is understood in connection with the Italian districts, not to speak of the American communities. In the brokering game that it plays between central power and 
local actors, the system of notables is at the opposite pole from the American ideal of community. In this ideal, a "community" is a unit of social action capable of mobilizing itself to resolve, without further ceremony, the problems of its survival and development (Grémion 1976:264); community was to be the antithesis of the state. In contrast, in France, via the notable system in particular, the state remained precisely the frame of reference which defined the action space for local actors. The system of notables impeded the widespread mobilization which would have allowed collectivities to resolve their problems from the inside. It condensed the collective action space. This in turn allowed the notable to position himself as an indispensable intermediary. The price of this system was steep: absence of information, stifling of conflicts, crushing of minorities, formalism of democratic procedures. All of these measures prevented the free play of groups, in order to permit the notable to have his hands free in negotiations with the state (Grémion 1976:267).

The fragmentation of local societies and the system of notables thus seem to go handin-hand, the notable having the function of representing the diversity of interests as those of the locality, a system in which he wields all the power, and therefore perpetuates. The traditional local system thus appears as an integral part of the system of regulation developed at the instigation of the central state in France. In this way we see the danger of equating "local" with community-based or endogenous.

\section{The development of postwar statist interventionism, and the liquidation of former local systems}

Under the influence of postwar state planning, the earlier system was challenged and many, perhaps most, of the older local industrial systems disappeared. The central state also promoted the decentralization that was later adopted. Let us take up both points.

In the postwar period, the state attempted to go beyond its role as a mere regulator and become an active agent of economic and social development (Grémion 1976:471). The system of cartels and understandings was essentially regulatory; in the postwar reconstruction process, it took on an actively directive role, which led it to shake up somewhat the old politico-economic order.

Even before the war, the economic climate had militated for a strengthening of the role of the state. Faced with the incompetence of the heads of family firms and politicians, a technocratic current held that the economy should be run by specialists-technicians, modern managers, and "enlightened" functionaries - in the name of efficiency (Bonin 1988:114 ss; cf. the importance of currents such as those of the Nouveaux Cahiers in the management environment, those of X-crise in the Polytechnique world, etc.). There was a widespread desire that the state should act as prime mover in the modernization process. To do this it had to gain new competences.

The Vichy regime had in fact already taken the first steps in this direction. A number of technocrats at the time regarded the Pétain dictatorship as a historic opportunity to force the conservative, traditional elements of society to accept the upheavals necessary for modernization, which the parliamentary system had bound hand and foot through the electoral system of the Third Republic. The modernizers believed that France was bogged down in a swamp of small family firms; they wanted concentration in the hands of 
specialists, a sort of dirigiste planning philosophy (Bonin 1988:122).

Though this current failed to take hold at the time, in part due to the war, it continued to mature through schools such as that of Uriage; and it made a forceful comeback after the war. The mixed economy took hold in part because management had shown its limits in the course of the previous period and had discredited itself politically in the war.

We will not go into detail here about all the economic policies of the successive Plans, of the 1960s and 1970s which organized the concentration and reorganization of the French economy. A few points will suffice.

Initially charged only with improving the spatial distribution of activities in France, the policy of Territorial Planning (Aménagement du Territoire) was transformed step by step, toward the end of the Gaullist period and then under President Pompidou into a key element of economic policy. It organized industrial groups, created massive industryport complexes, and developed active intervention at many levels of the system. The local systems formed the pockets of backwardness that economic modernization was meant to restructure. The only permissible reason for not pursuing concentration and growth in establishment size was said to be the size of markets, as noted in 1974 by the authors of an important INSEE report on The Industrial Transformation of France (INSEE 1974). Agreement was so widespread at the time that Marxists and state officials could speak the same language, the leftist economist C.Palloix being at one in this regard with J.Ferry, the vice-president of the CNPF, the employers' association (Saglio 1985).

Restructuring had major effects in all the old industrial zones; it led to the disappearance, with little resistance, of the old forms of organization of the local industrial systems.

The disappearance of these old systems was all the more dramatic in that it signaled not only the dissociation of the links that had once existed between the state and the firm, but also a serious challenge to the notable system itself.

In attempting to be more systematic, policy no longer aimed at activity-by-activity control. Its aim instead was to shape the general dynamics of the industrial economy. Specialized functional interventions were replaced by horizontal policies set up progressively by the state, culminating in the 1982-3 decentralization laws.

The success of such policies was not a given, however, since earlier regional reforms, such as that of 1964, had been absorbed and coopted by the local politico-administrative system (Grémion 1976).

But in the concern for planning - general, this time, and no longer just functional and sectoral - a new system of local/national relations was promoted. Responsibility was transferred toward subnational entities. Policies based on new forms of contracts were also used. The more general contracts (zonal contracts, countryside contracts, and then state/regional contracts, etc.) progressively supplanted the specialized, sectoral interventions of the previous system. There were dramatic implications for the notable system. The latter was characterized by vertical, specialized, and privileged relations between the notable and the central apparatus; the new system by means of contracts and management modes that are more "horizontal." They decompartmentalize the local system, so that it may be managed as a unified entity, not as a system of fragments, each of whose interests are brokered vis-à-vis the central government by the notable (Ganne 1985). 4 
Thus a real and general transformation of the politico-economic system had gradually occurred in France since the war. This transformation affects the type of relation between and the forms of regulation of localized systems and the central state. A new type of local system, initiated by the 1982-3 decentralization law, recognized a new moral entity in local collectivities: new capacities for decision-making, with control by the central state carried out a posteriori, and no longer a priori, as previously.

The transition from the republican state as a regulator to the postwar rationalizing state was paralleled by this passage from a society of representation, congruent with the notable system, to a society of organization (Grémion 1976:471). The idea was that mobilization should go all the way to the local level, where horizontal systems of cooperation would be developed.

This is nonetheless a long way from an endogenous model of local development; local systems do not have the independence which, according to some, is the guarantor of their efficacy. They are, if anything, created by the centralized system of political regulation. This logical relation between center and periphery was explicitly elaborated in the preparatory report of the Ninth Urban Plan, which advocated the establishment of local systems — based on the mobilization and coordination of endogenous resources - as an antidote to structures that were highly fragmented and uncoordinated.

\section{Towards a standardization of the local?}

These changes also explain the relative homogeneity observed in the recent restructuring at the local level. It is indeed according to an identical type of model that contracts governing plans for the development of medium-sized towns and regions are executed. Local differences and specificities are now only taken into account to the extent that they conform to the overall, highly normative framework. There are standardized formulae for evaluating requests for subsidies for investments in local infrastructure and mobilizing local actors. Little space exists for the affirmation of other, less normative, specificities. We observe, in other words, the creation of a "canon of the local."

Decentralization thus functions, paradoxically, as a unifying frame of reference. We are a long way, here, from the diversity of models of organization and local specificities that seem to characterize the Italian districts.

This dynamic of unification explains one of the paradoxes that we brought up in the introduction: it is no longer surprising to observe that the reinforcement of the local level is accompanied by greater indifference with regard to the localization of firms and that it encourages development of systems of networks that are more dispersed than localized (Ganne, et al. 1988). Decentralization appears to produce paradoxical, perverse effects.

It is thus in its overall context that the problem has to be resituated: the imposition of a single political model of management on the local level, by homogenizing the framework of action at that level, actually encourages economic actors to develop linkages outside their immediate local system. Submitted, as it were, to a single set of norms, the local no longer constitutes a problem to be controlled. The unification produced by decentralization thus promotes mobility of economic activity.

We observe in any case that there is a wide gap between the constitution of the local in contemporary France and Italy. It is important to avoid hasty assimilation of French 
developments to the Italian case.

\section{CONCLUSION}

What conclusions can be drawn about the functioning of the evolution of local industrial systems in France?

The maintenance of old industrial systems in France, far from being the result of local contingent social forces, existing, as it were on the margins of powerful structures, is better understood as an integral part of the centralized French administrative system.

The relatively closed and static nature of the old French industrial districts was congruent with the old form of political brokering at the territorial level which has been called the notable system.

Political authorities sought to break down these "feudal" features and the productivity blockages to which they led in the postwar years. More recently social and cultural homogenization has been pushed by the central state all the way down to the local level. The decentralization law has actually encouraged this trend.

It is to this political economy, which allows us to see how economics and politics become systems that shape each other mutually, that we must refer in order to understand the specificity of the French case, as well as its limits.

The paradox of the French case is precisely that it challenges contemporary stereotypes by insisting that local industrial systems again be placed within the context of the political administrative system. In doing so I have also sought to avoid both the neostructuralism of the Regulation School (i.e. the current wave of theorization on the subject of post-Fordism) and the neo-culturalist tendencies, which have been revived in the research on the Italian industrial districts (i.e. the increasing importance attributed to local cultures and enterprise cultures).

The risk at present is that the political level is being ignored.

In recent times, a certain fetishization of local development has arisen in response to the success of Italian industrial districts. This "neo-localism" creates several serious forms of confusion:

a) it conflates a number of cases which are in fact very different (Sfax in Tunisia, Cholet in France, Prato in Italy, etc.); 5

b) it perpetuates, the illusion of local autonomy;

c) it frequently confuses local systems with new forms of industrial organization based on flexible automation, and thus incorrectly confers an image of modernity on these local systems.

The French situation does, nonetheless, seem to provide an opportunity to reflect positively on the variety of local industrial systems. First, local systems can exist without being characterized, as in the Italian case, by local-horizontal integration of economic, social and political dynamics. The French local industrial system is based on local segmentation of these different aspects, each sphere (professional as well as political) favoring vertical relations with the central state.

Second, the local and the endogenous are not the same. If the number of local 
industrial systems between the wars was larger in France than in other countries, it was not because they were structured in a more deeply endogenous way, or because, as in Italy, they were endowed with a relative economic, social, and political homogeneity that made them more resistant than elsewhere. Rather, it was because these local industrial systems were more heavily regulated and closed in upon themselves, preserving and reproducing, by their mode of articulation with an overall politico-economic system, their fragmented mode of organization.

In the study of the districts and the local industrial systems, the problem is not to oppose the cultural and the economic, the local and the general, or the endogenous and the exogenous, as is implicit in much research, but to understand how differentiated, reciprocal forms of the economic and the cultural which are articulated by politics were mediated through the institutional system.

In the French case, reference to a centralized institutional state structure was indispensable. Whereas in the Italian case districts manage their competition directly, in France a regulating, redistributing state mediates the relationships between industrial systems. The state organizes economic policy, gives out subsidies, and regulates systems of social and professional relations. All of this is, in the final analysis, a question of political habits. It is thus essential to develop ways to contextualize the economic in order to develop a more effective economic sociology. 